\title{
The endocrine disruptor DEHP and the ECS: analysis of a possible crosstalk
}

\author{
Jana Ernst, Urszula Grabiec, Kathrin Falk, Faramarz Dehghani and Kristina Schaedlich \\ Department of Anatomy and Cell Biology, Faculty of Medicine, Martin Luther University Halle-Wittenberg, Halle (Saale), Germany
}

Correspondence should be addressed to J Ernst: jana.ernst@medizin.uni-halle.de

\begin{abstract}
Studies of the last decade associated the environmental contamination by di-(2-ethylhexyl)- $\quad$ Key Words phthalate (DEHP) with obesity and endocrine malfunction. DEHP was found to interact with $>$ adipocytes several receptors - among them are receptors of the endocannabinoid system (ECS) with D DEHP high expression levels in adipose tissue. Furthermore, the correlation for BMI and body fat $\rightarrow$ endocannabinoid system to the serum endocannabinoid level raises the question if the obesogenic and endocrine- $\quad$ leptin disrupting DEHP effects are mediated via the ECS. We therefore characterized the ECS in a human cell model of adipogenesis using the SGBS preadipocytes to subsequently investigate if DEHP exposure affects the intrinsic ECS. The receptors of the ECS and the endocannabinoid-metabolizing enzymes were upregulated during normal adipogenesis, accompanied by an increasing secretion of the adipokines adiponectin and leptin. DEHP affected the secretion of both adipokines but not the ECS, suggesting DEHP to alter the endocrine function of adipocytes without the involvement of the intrinsic ECS.

\section{Introduction}

During the last decades, environmental pollution as well as the prevalence of obesity and metabolic syndrome have increased (1). So, an environmental link to obesity is barely surprising $(2,3,4,5)$. Increasing evidence was found for an adverse impact on human health due to environmental agents, such as phthalates (6). Di-(2ethylhexyl)-phthalate (DEHP) has belonged to the most abundant phthalates in industry and consumer goods for many years acting as an endocrine-disrupting chemical (7). As DEHP is not covalently bound to PVC, it easily migrates into the environment and by that accumulates in lipophilic products like cosmetics or food and binds to house dust particles (8). Associations to numerous health problems, including obesity, diabetes and the metabolic syndrome, have been observed by epidemiological studies $(9,10,11,12,13)$. Furthermore, investigations in mice identified DEHP as an obesogen by increasing food intake, body weight, fat mass, serum leptin and decreasing serum adiponectin $(14,15,16)$. Accordingly, data from in vitro models showed a DEHP-dependent impairment of adipogenesis and adipocyte function $(14,17)$. Analyses on underlying mechanisms are difficult, because energy metabolism and endocrine homeostasis involve complex regulatory systems - among them is the endocannabinoid system (ECS). Endocannabinoids are endogenous ligands of the G-protein-coupled cannabinoid receptors, imitating several effects of the pharmacological active substance $\Delta 9$-tetrahydrocannabinol (THC) from cannabis sativa (18). Endocannabinoids like the N-arachidonoylethanolamine (AEA) and 2-arachidonoylglycerol (2-AG) mediate their effects via $\mathrm{CB}_{1}$ and $\mathrm{CB}_{2}$ cannabinoid receptors $(19,20,21)$, but also via the recently identified GPR55 (22) and noncannabinoid receptors like the transient receptor potential vanilloid 1 (TRPV1) (23) or the peroxisome proliferatoractivated receptors (PPARs) (24). Endocannabinoid levels are regulated by the synthesizing enzymes $\mathrm{N}$-acylphosphatidylethanolamine phospholipase D (NAPE-PLD) and diacylglycerol lipase (DAGL) $(25,26)$ as well as by the metabolizing fatty acid amide hydrolase (FAAH) and monoacylglycerol lipase (MAGL) $(27,28)$.

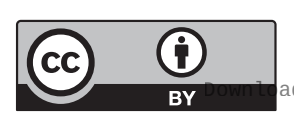

This work is licensed under a Creative Commons Attribution 4.0 International License. ded from Bioscientifica.com at 04/26/2023 11:18:14AM 
The influence of phthalates on ECS in peripheral organs is poorly investigated. However, the effect of di-isononyl phthalate (DiNP) as one of the dominating alternatives to DEHP was studied in fish models demonstrating a deregulation of the intrinsic ECS in the gonads, the liver as well in the hepatic lipid metabolism $(29,30,31)$. DiNP exhibited adipogenic activity in murine 3T3-derived adipocytes (32).

Adipose tissue expression of ECS components differs between lean and obese subjects as reflected by altered blood endocannabinoid levels $(33,34,35,36,37)$. Literature in the field of ECS, adipogenesis and adipose tissue as a metabolic and endocrine organ still draw a blurred picture of possible interactions. $\mathrm{As}^{\mathrm{CB}_{1}}$ activation promotes adipocyte proliferation and differentiation, it furthermore positively affects insulin-stimulated but not basal glucose uptake in 3T3-derived adipocytes $(38,39,40)$. Accordingly, an increase of glucose uptake after activation of $\mathrm{CB}_{1}$ was demonstrated in human primary adipocytes - accompanied by calcium influx and translocation of GLUT4. However, adiponectin and leptin were not altered (41). The inhibition of $\mathrm{CB}_{1} \mathrm{R}$ in adipocytes directly reduced the leptin secretion in mice. In line with these results, an in vitro study in 3T3-derived adipocytes confirmed increased leptin levels after treatment with different $\mathrm{CB}_{1} \mathrm{R}$ agonists that were inhibited by the employment of a $\mathrm{CB}_{1} \mathrm{R}$ inverse agonist (42). In human adipose tissue, no association was found between CNR1-mRNA level and adiponectin expression, its secretion or circulating adiponectin (43). After $\mathrm{CB}_{1}$ antagonism in rats, a higher adipose gene expression and serum level of adiponectin was detected. This finding was proposed as a consequence of reduced food intake (44). Contrary to the assumption of an indirect effect, the in vitro blockade of $\mathrm{CB}_{1}$ led to an upregulation of adiponectin in 3T3-derived adipocytes $(38,39,45)$. THC also elevated adiponectin gene expression in this cell line. The authors discussed that the variety of different types and concentrations of $\mathrm{CB}_{1}$-manipulating agents may likely be responsible for the miscellaneous effects among studies (46). Comparing different ligands of the ECS in human bone marrow derived adipocytes, an exclusive activation of $\mathrm{CB}_{1}$-inhibited adipogenesis paralleled by a reduction of adiponectin. Nevertheless, these effects of $\mathrm{CB}_{1}$ activation were diminished when ligands not only bound to $\mathrm{CB}_{1}$ but also to the non- $\mathrm{CB}_{1} / \mathrm{CB}_{2}$ receptor PPARgamma, which is a crucial transcription factor of adipogenesis (47).

To date there are no reports on the relationship between DEHP and the ECS in obesity. The known fact of interactions of DEHP with receptors of the ECS $(48,49)$ raised the question whether obesogenic and endocrine-disrupting DEHP effects in adipocytes are mediated via the ECS. For the present study, we first characterized the intrinsic ECS in a human cell model of adipogenesis using the Simpson-Golabi-Behmel Syndrome (SGBS) preadipocytes followed by investigating the impact of DEHP on the ECS as an endocrine modulator of the adipokine system.

\section{Materials and methods}

\section{Chemicals}

DEHP was dissolved in dimethyl sulfoxide (DMSO), both purchased from Sigma-Aldrich, and stored as a 1000-fold stock solution until further use.

\section{Cell culture}

The SGBS preadipocytes were kindly provided by Prof M Wabitsch (Division of Pediatric Endocrinology and Diabetes, Department of Pediatrics and Adolescent Medicine, Ulm University Medical Center, Ulm, Germany). These preadipocytes are a non-immortalized cell model for adipogenesis cultured and differentiated as described previously without modifying the protocols $(50,51)$. During the induction phase (day 0 to day 4$)$, cells were exposed to a final DEHP concentration of $128 \mu \mathrm{M}$ (50 $\mu \mathrm{g} / \mathrm{mL}$ ) and a concentration of $0.1 \%$ DMSO in the culture media, whereas controls were run as vehicle controls with $0.1 \%$ DMSO only. These experimental conditions are based on in-vitro investigations of our group previously performed in murine C3H10-T1/2 mesenchymal stem cells identifying the induction phase as a particularly vulnerable exposure window of adipogenesis $(17,52)$ and in the SGBS cell model revealing effective but non-toxic concentrations of used substances (53). Furthermore, the herein applied DEHP concentration is considered as environmentally relevant $(54,55,56)$. At day 8 of differentiation, all experiments have been finalized. Samples were taken at day 0, 4 and 8 of adipogenesis.

\section{Quantitative real-time PCR}

Quantitative realtime PCR (qRT-PCR) was performed to measure the mRNA expression levels in a StepOnePlus ${ }^{\mathrm{TM}}$ Real-Time PCR System (Applied Biosystems). Plasmid standards were generated based on a gene-specific target sequence. Absolute mRNA copies were calculated by quantitative standard curves using serial dilutions $\left(10^{6}\right.$, $10^{5}, 10^{4}$ and $10^{3}$ ) of gene-specific plasmid standards.
This work is licensed under a Creative Commons Attribution 4.0 International License. ded from Bioscientifica.com at 04/26/2023 11:18:14AM via free access 
Assays were run with duplicates of each cDNA sample as well as a no template control (NTC) in a 96-well format for the following genes: ADIPOR1 and ADIPOR2, CNR1 and CNR2, DAGLalpha, FAAH, GLUT1 and GLUT4, GPR55, LEPR, MAGL, NAPE-PLD and TRPV1. For normalization, we analyzed the expression of the housekeeping gene TATAbox-binding protein $(T B P)$. Absolute mRNA expression was calculated as copy number per $10^{3}$ molecules TBP. The primers and amplicons were as shown in Table 1.

\section{Hormone assay}

Cell supernatants were collected to measure the concentrations of leptin (high sensitive Leptin ELISA, IBL, Hamburg, Germany) and adiponectin (Quantikine ${ }^{\circledR}$ ELISA Human Total Adiponectin/Acrp30, BioVendor, Kassel, Germany) by ELISA according to manufacturer's manual. ELISA data were normalized to the protein concentration of individual samples. Protein was isolated using radioimmunoprecipitation assay (RIPA) buffer including protease and phosphatase inhibitors (Roche). Protein concentration was determined by the BioRad Protein Assay (BioRad).

\section{Western blot}

For protein analyses of ECS components, cells were harvested in lysis buffer containing $80 \mathrm{mM}$ Tris, $70 \mathrm{mM}$ sodium dodecyl sulfate (SDS), $0.3 \mathrm{M}$ saccharose, $3 \mathrm{mM}$ sodium orthovanadate and $0.5 \mathrm{mM}$ phenylmethylsulfonyl floride (PMSF) at $\mathrm{pH}$ 7.4. Samples of $40 \mu \mathrm{g}$ protein were separated by a $12.5 \%(\mathrm{w} / \mathrm{v})$ SDS-polyacrylamid gel before blotting onto nitrocellulose membrane (Protran BA 85, GE Healthcare). Non-specific protein-binding sites were blocked for 30 min with 5\% (w/v) milk (Carl Roth, Karlsruhe, Germany) or 10\% (v/v) Roti-block solution (Carl Roth) in TBST. For protein detection, primary antibodies against $\mathrm{CB}_{1}$, DAGLalpha and DAGLbeta, FAAH, MAGL and NAPE-PLD as well as against beta-ACTIN and GAPDH as housekeeping proteins were used (Table 2). Membranes were incubated for $16 \mathrm{~h}$ at $4^{\circ} \mathrm{C}$. They were subsequently washed and the horseradish peroxidaseconjugated secondary antibodies (Table 2) were applied for $1 \mathrm{~h}$ at room temperature. Chemiluminescence detection was performed by Luminata Forte (Millipore). ImageJ analysis software version 1.46r (National Institutes of Health, Laboratory for Optical and Computational Instrumentation, University of Wisconsin, Madison, WI, USA) was used for the analysis of the intensity of the immunoreactive bands.

\section{Immunohistochemical staining}

Fifty thousand SGBS cells were plated on PLL (Millipore) covered glass plates and treated according to the protocol (see 'Cell culture' section). On day 0, 4 and 8 cells were fixed with $4 \%$ paraformaldehyde for $25 \mathrm{~min}$. Before staining, the cells were washed with $0.02 \mathrm{M}$ PBS and incubated with goat serum (Sigma-Aldrich) for $30 \mathrm{~min}$. Primary antibodies against $\mathrm{CB}_{1}$, DAGLalpha and DAGLbeta, FAAH, MAGL and NAPE-PLD (Table 2) were diluted in $0.05 \%$ BSA (Sigma-Aldrich) and incubated overnight. The next day, cells were washed three times with PBS/Triton and incubated with a HRP-labelled

Table 1 Primers for quantitative RT-PCR.

\begin{tabular}{lll}
\hline Gene & & Accession number \\
\cline { 1 - 1 } ADIPOR1 & & NM_001290629 \\
ADIPOR2 & & NM_024551 \\
CNR1 & & NM_033181 \\
CNR2 & & NM_001841 \\
DAGLa & & NM_006133 \\
FAAH & & NM_001441 \\
GLUT1 & & NM_006516 \\
GLUT4 & & NM_001042 \\
GPR55 & & NM_005683 \\
LEPR & & NM_002303 \\
MAGL & NM_007283 \\
NAPE-PLD & NM_198990 \\
TBP & NM_003194 \\
TRPV1 & NM_080704 \\
\cline { 1 - 2 }
\end{tabular}

\begin{tabular}{l} 
Forward primer \\
\hline TGCGGCGGGGAGTTTAGAAG \\
GAGACACGCGGATCAACTCA \\
CTCAGTCATTTTGAGCTCAGCC \\
GCTCCTCATCTGTTGGTTCC \\
AGAATGTCACCCTCGGAATG \\
TCAAGGAGTGCTTCACCTACAAG \\
TGGCATCAACGCTGTCTTCT \\
ACTGGCCATTGTTATCGGCA \\
GGTGCTCTCCCTCCCATT \\
ACACCAGAGTGATGCAGGTTT \\
ATCACCATTCCCCAAATTGA \\
TCACGGATCCCATCTTTAGC \\
TGTGCTCACCCACCAACAAT \\
TGACCCTCCTGGTGGAGA
\end{tabular}

\begin{tabular}{l}
\hline Reverse primer \\
\hline CGTGTCAGCTTCCCTGTTACT \\
GTTGGTGCCCTTTTCTGAGC \\
GCCATGTCACCTTTGATGTCTTC \\
TGACCATGGAGTTGATGAGGC \\
GGTTGTAGGTCCGCAGGTTA \\
GTCATAGCTGAACATGGACTGTG \\
CTAGCGCGATGGTCATGAGT \\
GTCAGGCGCTTCAGACTCTT \\
GCTCACCAGTAGCGGGTAAC \\
ATGCTCAAACGTTTCTGGCTTC \\
GATGTACCAGCCCTTCTGGA \\
TCTCACAGCCACATTTTTGC \\
AGTCGTCTTCCTGAATCCCT \\
CTGCAGCAGGAACTTCACG
\end{tabular}

\begin{tabular}{|c|c|}
\hline $\mathbf{T}_{\mathbf{m}}\left({ }^{\circ} \mathrm{C}\right)$ & Amplicon (bp) \\
\hline 63 & 245 \\
\hline 60 & 175 \\
\hline 60 & 153 \\
\hline 60 & 125 \\
\hline 60 & 150 \\
\hline 60 & 164 \\
\hline 60 & 212 \\
\hline 60 & 213 \\
\hline 60 & 172 \\
\hline 62 & 187 \\
\hline 60 & 204 \\
\hline 60 & 243 \\
\hline 60 & 199 \\
\hline 60 & 158 \\
\hline
\end{tabular}

adiponectin receptor 1 and 2 (ADIPOR1 and ADIPOR2), cannabinoid receptor 1 and 2 (CNR1 and CNR2), diacylglycerol lipase alpha (DAGLa), fatty acid amide hydrolase (FAAH), glucose transporter 1 and 4 (GLUT1 and GLUT4), G protein-coupled receptor 55 (GPR55), leptin receptor (LEPR), monoacylglycerol lipase (MAGL), N-acylphosphatidylethanolamine phospholipase D (NAPE-PLD), TATA-box binding protein (TBP) and transient receptor potential vanilloid 1 (TRPV1).

https://ec.bioscientifica.com https://doi.org/10.1530/EC-19-0548 (c) 2020 The authors Published by Bioscientifica Ltd

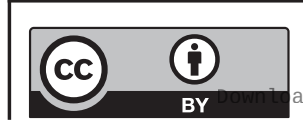

This work is licensed under a Creative Commons Attribution 4.0 International License. ded from Bioscientifica.com at 04/26/2023 11:18:14AM 
Table 2 Antibodies for Western blot (WB) and immunohistochemistry (IHC).

\begin{tabular}{l}
\hline \\
\hline Primary antibody \\
Rabbit polyclonal antibody against $\mathrm{CB}_{1}$ \\
Rabbit pig antibody against DAGLalpha \\
Rabbit antibody against DAGLbeta \\
Rabbit antibody against human FAAH \\
Rabbit polyclonal antibody against human MAGL \\
Rabbit polyclonal antibody against human NAPE-PLD \\
Mouse antibody against human beta-ACTIN \\
Rabbit antibody against human GAPDH \\
Secondary antibody \\
Anti-rabbit-IgG \\
Anti-mouse-IgG \\
Anti-rabbit-IgG
\end{tabular}

\begin{tabular}{|c|c|}
\hline Dilution WB & Dilution IHC \\
\hline $\begin{array}{l}0.5 \mu \mathrm{g} / \mathrm{mL} \\
1: 2000 \\
1: 1000 \\
1: 1000 \\
1: 1000 \\
1: 1000 \\
1: 5000 \\
1: 1000\end{array}$ & $\begin{array}{l}1.65 \mu \mathrm{g} / \mathrm{mL} \\
1: 200 \\
1: 100 \\
1: 200 \\
1: 200 \\
1: 200\end{array}$ \\
\hline $\begin{array}{l}1: 20,000 \\
1: 10,000\end{array}$ & $1: 2$ \\
\hline
\end{tabular}

Manufacturer
Cayman, Mississippi, USA
Frontier Institute, Hokkaido, Japan
Thermo Scientific, Dreieich, Germany
Cayman
Cayman
Cayman
Cell Signaling, Boston, USA
Cell Signaling
Vektor laboratories, Burlingame, CA
Vektor laboratories
DAKO, Hamburg, Germany

aThis primary antibody is already horseradish peroxidase-conjugated and does not require any secondary antibody. cannabinoid receptor $1\left(\mathrm{CB}_{1}\right)$, diacylglycerol lipase alpha and beta (DAGLalpha and DAGLbeta), fatty acid amide hydrolase (FAAH), glyceraldehyde 3-phosphate dehydrogenase (GAPDH), monoacylglycerol lipase (MAGL), N-acylphosphatidylethanolamine phospholipase D (NAPE-PLD).

secondary antibody diluted in PBS for $1 \mathrm{~h}$. After washing with PBS, cells were covered with $0.05 \mathrm{M}$ Tris buffer and exposed to DAB (Sigma-Aldrich) for $5 \mathrm{~min}$. Finally, hematoxylin (Carl Roth) staining was performed and the plates were covered with Entallan (Millipore).

\section{Statistical analyses}

At least four independent experiments $(\mathrm{N})$ were performed for each group. Data was presented as mean \pm s.E.M. For expression analyses during adipogenesis without DEHP exposure, the values of the DMSO control group at day 0 was defined as reference and the ANOVA with the Bonferroni's post hoc test performed. To evaluate differences between the DMSO control group and the DEHP exposure group, an unpaired Student's $t$-test or the Wilcoxon rank-sum test were used. Data differences were considered as statistically significant at $P$ value $\leq 0.05$.

\section{Results}

\section{DEHP alters the secretion of adiponectin and leptin during adipogenesis}

To evaluate the efficacy of our experimental conditions on adiponectin and leptin, their receptors and the glucose transporters were investigated as adipogenic markers (Fig. 1). During normal adipogenesis, the secretion level of both adipokines were significantly increased at day 4 and 8 for leptin and at day 8 for adiponectin compared to day 0. DEHP exposure led to significantly reduced adiponectin and increased leptin values at day 8 (Fig. 1A). Gene expression of receptors ADIPOR2 and LEPR was not significantly altered (both with $P=0.06$ during normal adipogenesis). DEHP had no influence on their gene expression (Fig. 1B). ADIPOR1 was not expressed. During normal adipogenesis, both investigated glucose transporters showed alterations with a significant decrease of GLUT1 at day 4 and 8, whereas GLUT4 increased at day 8. No effect of DEHP exposure was detected for both glucose transporters (Fig. 1C).
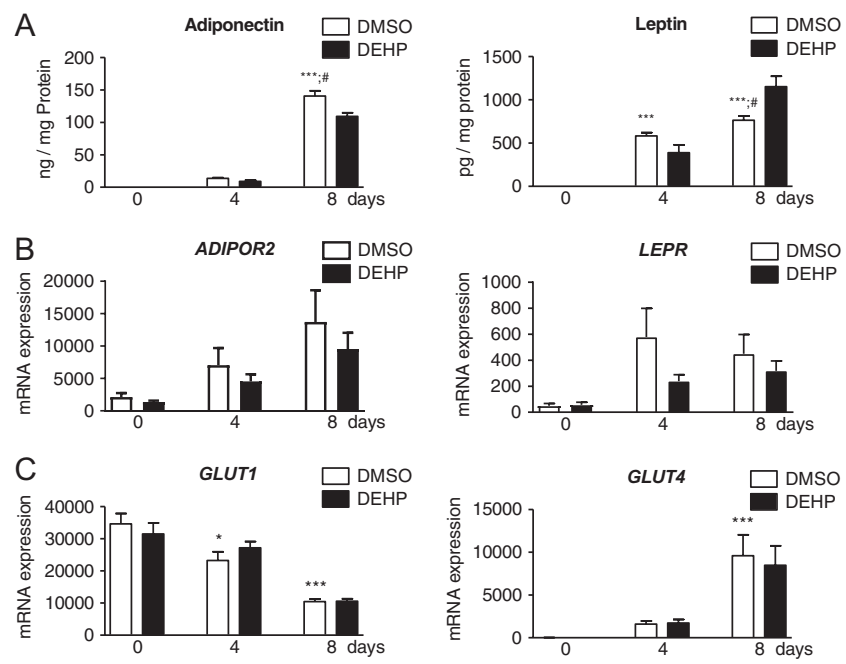

Figure 1

Adipokines, their receptors and the glucose transporters in the SGBS cell model during normal and DEHP-exposed adipogenesis. The secretion of adiponectin and leptin was measured (A). Additionally, the gene expression of their receptors, adiponectin receptor 2 (ADIPOR2) and leptin receptor (LepR) (B), and the glucose transporters GLUT1 and GLUT4 (C) was evaluated in SGBS cells during adipogenic differentiation with and without DEHP. Absolute mRNA expression is presented copy number per 1000 molecules TBP. $n=6$ for secretion; $n=8$ for mRNA expression; ${ }^{*} P \leq 0.05$; $* \star P \leq 0.01 ; * * * P \leq 0.001$ for comparing normal adipogenesis to day 0 ; $\# P \leq 0.05$ for comparing the unexposed and DEHP-exposed group. 
The receptors and the metabolizing enzymes of the ECS were differentially expressed during normal adipogenesis

The expression of components of ECS was studied during adipogenesis in SGBS cells (Fig. 2). CNR2 and GPR55 were absent at detectable expression levels. The expression of the receptor TRPV1 was significantly upregulated at day 4 and remained at a high level until day 8 (Fig. 2B). Another receptor, CNR1, was significantly and transiently upregulated at day 4 and showed a decline at day 8 when compared to day 0 values (Fig. 2C). FAAH expression was increased at day 4 and day 8 (Fig. 2D). An elevation in MAGL expression was found at day 8 only (Fig. 2E). Data on endocannabinoidsynthesizing enzymes showed no alteration for NAPE-PLD and DAGLalpha expression (Fig. 2F and G).

\section{DEHP did not affect the expression of the ECS}

After investigating the expression of the ECS during normal adipogenesis, SGBS cells were exposed to DEHP within the induction phase, and its influence on mRNA and protein levels was measured (Fig. 2). DEHP did not significantly change the expression of TRPV1, CNR1, FAAH, MAGL, NAPE-PLD and DAGLalpha (Fig. 2B, C, $\mathrm{D}, \mathrm{E}, \mathrm{F}$ and $\mathrm{G})$. This was verified for $\mathrm{CB}_{1}$, FAAH, MAGL, NAPE-PLD and DAGL at protein level (Fig. 2C, D, E, F and $\mathrm{G})$. Western blots for $\mathrm{CB}_{2}$, GPR55 and TRPV1 could not be performed due to a lack of appropriate specific antibodies.

Furthermore, immunohistochemical studies were performed. During induction phase, SGBS cells grew mostly remaining spindle shaped. With increasing differentiation, cells became larger with expanded somata and visible lipid droplets. Additionally, only few isolated, very small cells were present in cultures (Fig. 3). All investigated ECS components were expressed in fully differentiated SGBS adipocytes. Comparing the data obtained from qRT-PCR, Western blot and immunohistochemistry describes an ECS component-specific characteristic pattern during adipogenesis with partial discrepancy. $\mathrm{CB}_{1}$ and FAAH immunoreactivities were evident in the somata of day 8-adipocytes with only very few positive cells at
A
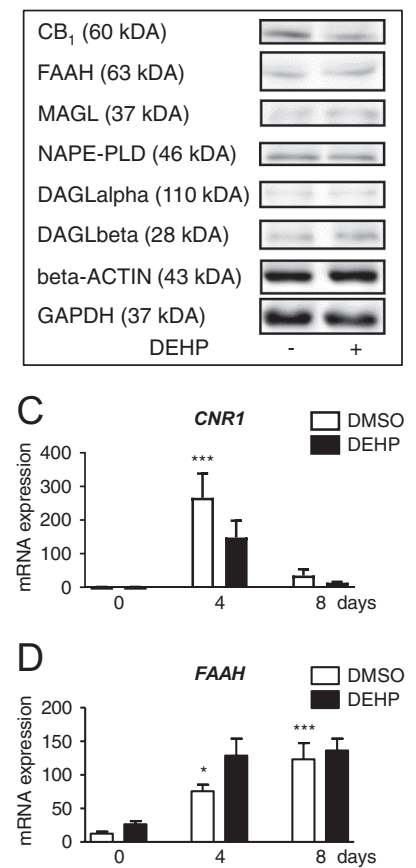

B
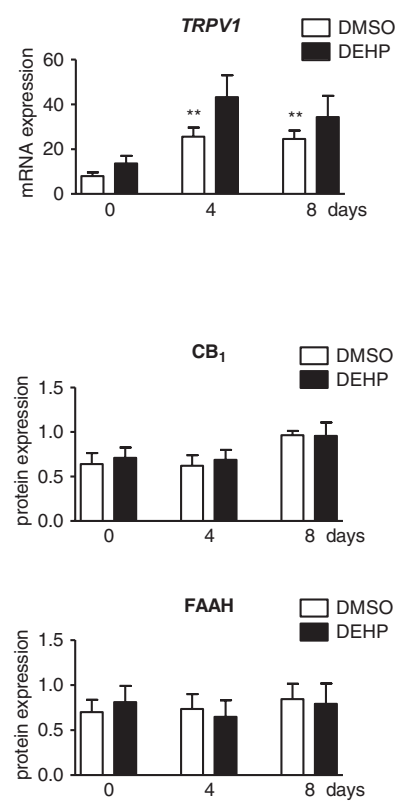

E
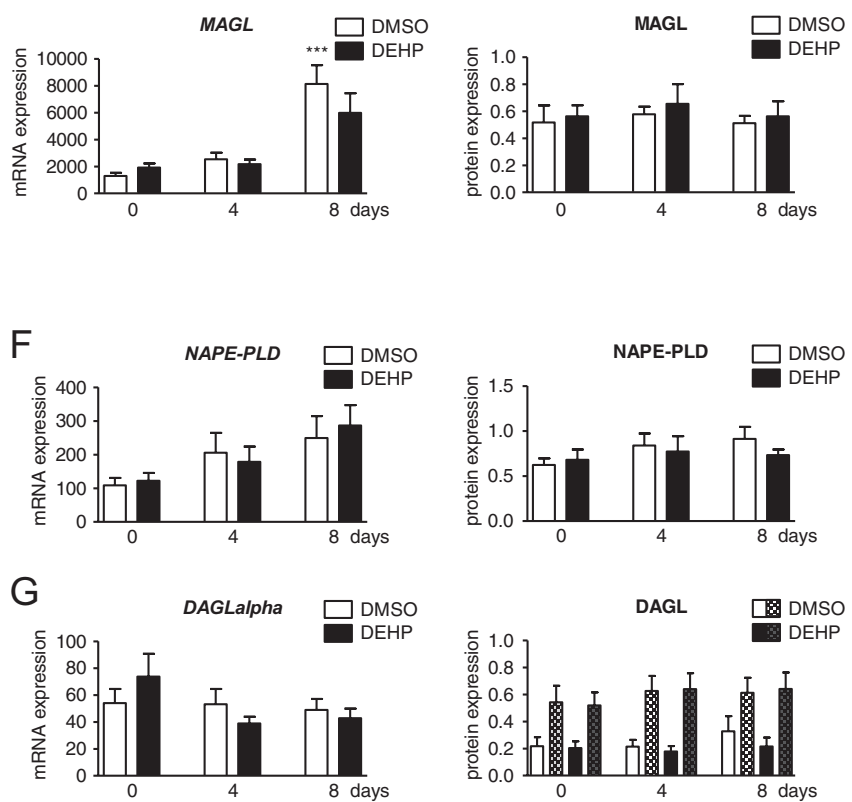

Figure 2

The endocannabinoid system (ECS) in the SGBS cell model during normal and DEHP-exposed adipogenesis. Western blot analyses of CB ${ }_{1}$, FAAH, MAGL, NAPE-PLD, DAGLalpha and DAGLbeta comparing unexposed and mature (day 8) DEHP-exposed SGBS cells were normalized to the endogenous reference beta-ACTIN and GAPDH, respectively (A). Gene and protein expression of the receptors transient receptor potential vanilloid 1 (TRPV1) (B) and the cannabinoid receptor $1\left(C N R 1, C B_{1}\right)(C)$, the enzymes fatty acid amide hydrolase (FAAH) (D), monoacylglycerol lipase (MAGL) (E), $\mathrm{N}$-acylphosphatidylethanolamine phospholipase D (NAPE-PLD) (F) and diacylglycerol lipase alpha (DAGL) (G) were determined in SGBS cells with and without DEHP exposure. For DAGL, the protein expression of both isoforms was evaluated with DAGLalpha as blank columns and DAGLbeta as patterned columns within one figure (G). Absolute mRNA expression is presented copy number per 1000 molecules TBP. $n \geq 8$ for gene expression; $n \geq 4$ for protein expression; ${ }^{\star} P \leq 0.05 ;{ }^{*} P \leq 0.01 ;{ }^{* \star *} P \leq 0.001$ for comparing normal adipogenesis to day $0 ;{ }^{*} P \leq 0.05$ for comparing the unexposed and DEHP-exposed group.

https://ec.bioscientifica.com https://doi.org/10.1530/EC-19-0548 (c) 2020 The authors Published by Bioscientifica Ltd

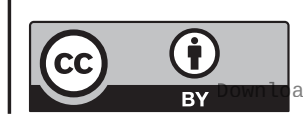

This work is licensed under a Creative Commons Attribution 4.0 International License. ded from Bioscientifica.com at $04 / 26 / 2023$ 11:18:14AM 
days 0 and 4 (Fig. 3A and B). A rather weak immunoreactivity was observed for MAGL at day 4. At day 8, MAGL was stained with stronger intensity mainly located around lipid droplets (Fig. 3C). NAPE-PLD immunoreactivity was found at day 4 and with much stronger intensity at day 8 (Fig. 3D). Whereas DAGLalpha positive cells were particularly abundant at days 0 and 4 , a weak DAGLalpha immunoreactivity was observed at day 8 of adipogenesis (Fig. 3E). DAGLbeta-positive cells were more abundant and intensely stained than DAGLalpha positive cells (Fig. 3F). Notably, for all ECS components, no difference was detected between the DEHP-exposed and the DMSO-control group at all days investigated (Fig. 3A, B, C, D, E and F).

\section{Discussion}

The present study aimed to investigate whether the obesogenic and endocrine-disrupting DEHP effects in adipocytes were mediated via the ECS. At first, we characterized the intrinsic ECS during normal adipogenic differentiation from SGBS preadipocytes to mature adipocytes. The receptors CNR1 and TRPV1 and the endocannabinoid-metabolizing enzymes $F A A H$ and $M A G L$ as well as the endocannabinoid-synthetizing enzymes NAPE-PLD and DAGLalpha were expressed. CNR2 and GPR55 - two additional receptors - were not detectable. The findings on CNR2 are in agreement with data from bone marrow derived adipocytes (47). Also, expression and binding assays performed in human s.c. adipose tissue revealed a functional expression for $\mathrm{CB}_{1}$ and TRPV1, but not for $\mathrm{CB}_{2}$ (57). The presence of $\mathrm{CB}_{2}$ in adipose tissue has been a matter of controversy. An earlier study postulated contaminations with vascular, blood and immune cells as a potential source of positive $\mathrm{CB}_{2}$-findings (41). In our cell model, a contamination can be ruled out. By further analysing the expression pattern of CNR1 and TRPV1, we found both receptors to be upregulated during the induction phase followed by a decrease during differentiation. For $\mathrm{CB}_{1}$, an increasing
A
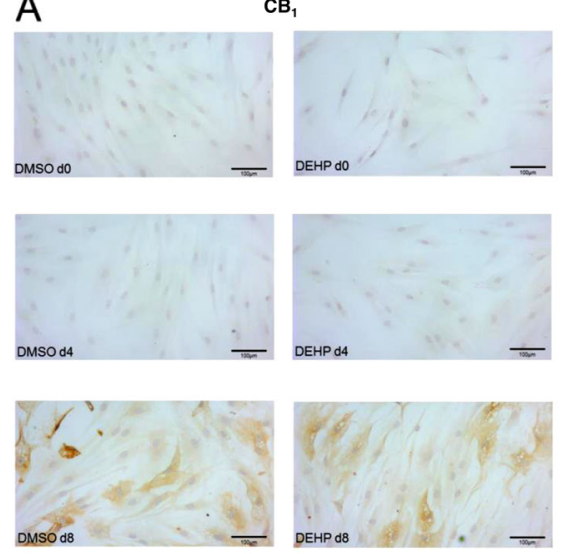

D
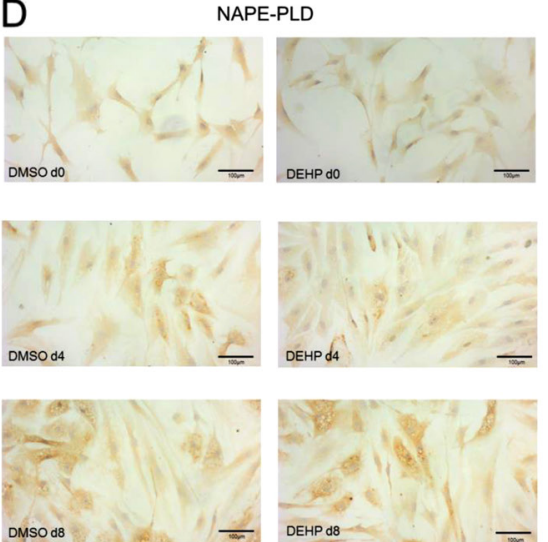

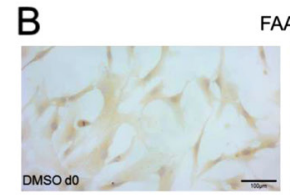

FAAH
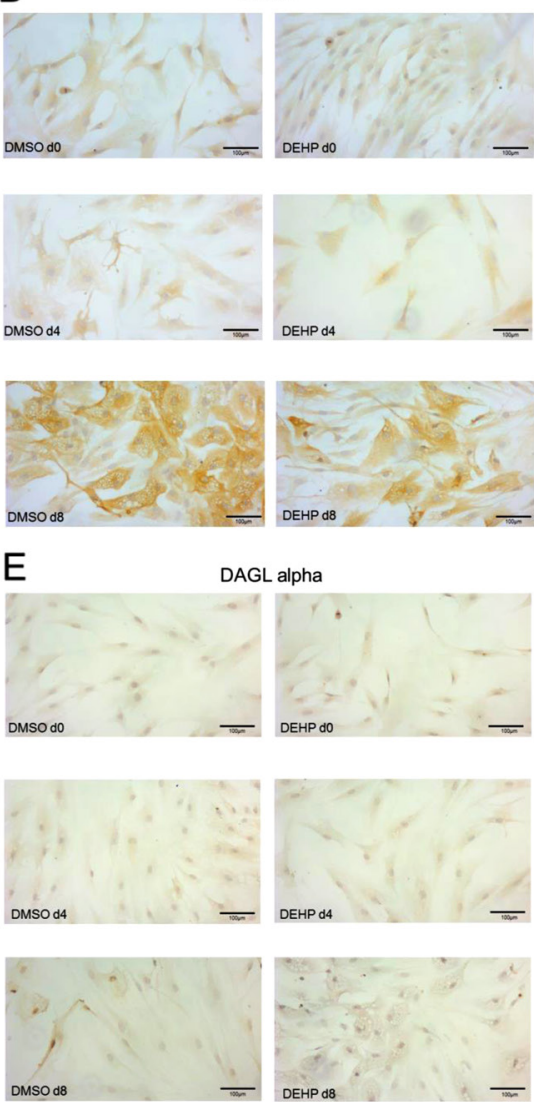
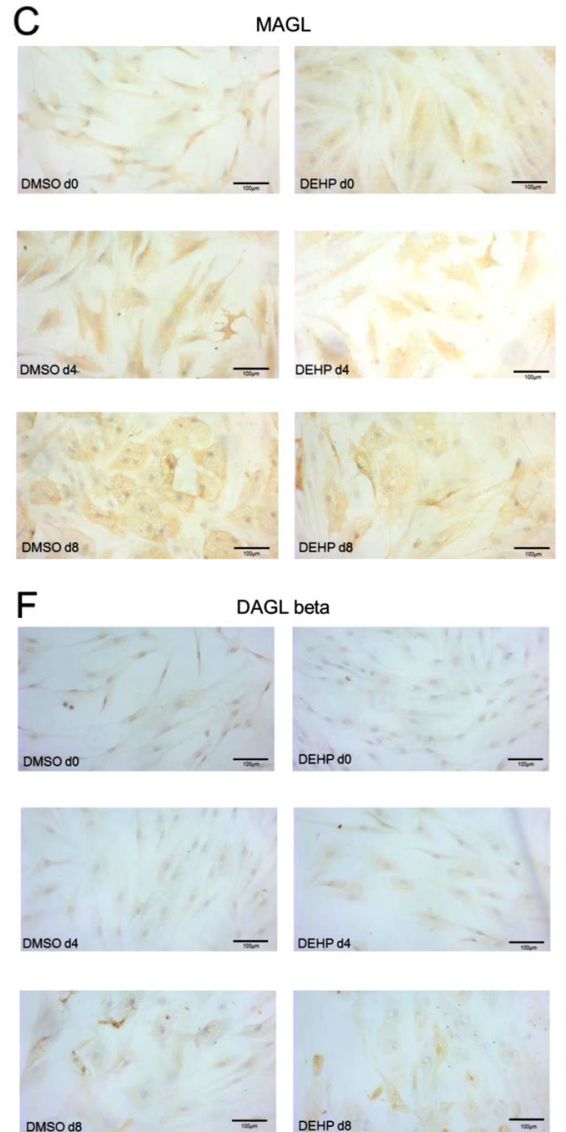

Figure 3

The localization of the ECS in the SGBS cell model with and without DEHP treatment. Immunohistochemical staining of CB 1 (A), FAAH (B), MAGL (C), NAPE-PLD (D), DAGLalpha (E) and DAGLbeta (F) in SGBS cells at day 0, 4 and 8 after treatment with DMSO or DEHP (scale bar $=100 \mu \mathrm{m})$.

https://ec.bioscientifica.com https://doi.org/10.1530/EC-19-0548 (c) 2020 The authors Published by Bioscientifica Ltd

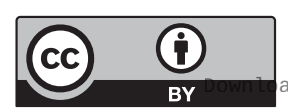

This work is licensed under a Creative Commons Attribution 4.0 International License. ded from Bioscientifica.com at $04 / 26 / 2023$ 11:18:14AM 
immunoreactivity was detectable throughout maturation. In human bone marrow derived adipocytes, CNR1 and TRPV1 also increased after induction of adipogenesis. Additionally, a $\mathrm{CB}_{1}$-dependent inhibition of the differentiation was demonstrated, while otherwise AEA promoted adipogenesis by transactivation of PPARgamma (47). Comparing cannabinoid receptor expression in human primary fat cells before and during adipogenic differentiation, it was shown that CNR1 was not expressed in preadipocytes, but rapidly appeared with differentiation, whereas CNR2 started at low levels to become undetectable (41). In contrast, in preadipocytes and mature adipocytes isolated from human omental and s.c. adipose tissue, CNR1 and CNR2 were present in both cell types, but were more abundant in mature adipocytes. Interestingly, CNR2 was much higher expressed than CNR1 with functional proteins for both (58). A functional expression of $\mathrm{CB}_{1}, \mathrm{CB}_{2}$ and TRPV1 in murine 3T3-derived adipocytes was demonstrated during adipogenesis with increasing $\mathrm{CB}_{1}$ but declining $\mathrm{CB}_{2}$, whereas TRPV1 was unchanged (40). Investigating the protein expression pattern of the enzymes responsible for synthesis or degradation of main endocannabinoids namely $2-A G$ and AEA in the SGBS cell model showed: (a.) a slight increase in immunoreactivity of both DAGLalpha and MAGL for metabolizing 2-AG and (b.) no change in NAPE-PLD accompanied by an increase in FAAH immunoreaction for AEA during adipogenesis. The findings might point to a more or less constant 2-AG and a decrease in AEA levels. Studies with activity and expression data demonstrated a functional expression of enzymes involved in biosynthesis and hydrolysis of endocannabinoids in human s.c. and abdominal adipose tissue $(41,57)$. Differentiation of murine 3T3-derived adipocytes was accompanied by an increasing degradation of AEA by FAAH, whereas synthesis by NAPE-PLD was not influenced. Additionally, AEA was found to enhance - via $\mathrm{CB}_{1}$ - the insulinregulated glucose uptake, that typical increases during adipogenic maturation (40). Furthermore, stimulation of murine 3T3-derived adipocytes with leptin decreased AEA and 2-AG levels (45). As adipogenic differentiation is paralleled by increasing leptin levels, the reduction of endocannabinoids by upregulation of endocannabinoidmetabolizing enzymes during adipogenesis may be the consequence of leptin-mediated regulation.

Concordant to previous data (50), the typical adipocyte markers leptin, adiponectin and GLUT- were upregulated during adipogenic maturation of SGBS adipocytes. Our investigations include not only the insulin-regulated glucose transporter GLUT4 but also the basal glucose transporter GLUT1. In contrast to the increase of GLUT4, we found GLUT1 to be reduced. This is in agreement with results of previous studies in human adipocyte precursor cells, assuming differentiation to be correlated with the development of insulin sensitivity in mature adipocytes $(59,60)$. As already described, DEHP exposure did not influence cell proliferation, but impaired adipogenic differentiation and lowered the lipid content of mature adipocytes (53). In proof of the efficacy of the present experiments, we investigated the DEHP action on adipokines. In agreement to our recent data (53), adiponectin was decreased and leptin was increased after DEHP exposure in mature SGBS adipocytes. Notably, in murine 3T3-derived adipocytes, DEHP reduced the cellular lipid content and adiponectin but increased the cell proliferation (14). In contrast, the higher number of adipocytes and the enhanced adipogenic differentiation of the murine mesenchymal stem cell line C3H/10T1/2 by DEHP exposure were associated with an increase of adiponectin expression (17). In vivo, DEHP exposure of mice and rats caused a gain of fat mass and a decrease of the serum adiponectin but increase of serum leptin (14, $15,16,61)$. Environmental contamination by DEHP is associated with human obesity $(9,12,13)$. Interestingly, a positive correlation to the BMI and body fat was found for the circulating levels of endocannabinoids, whereas obesity was linked to a reduced adipose expression of Cnr1 and FAAH $(34,35,45)$. DEHP was found to interact with receptors of the ECS, namely $\mathrm{CB}_{1}$ and PPARs $(48,49)$. The herein investigated receptors and enzymes of the ECS were not altered by DEHP. As shown before, DEHP did not affect the protein amount of PPARalpha and PPARgamma in SGBS (53). However, DEHP-mediated alterations on PPARs was reported in both directions as assessed in rodent in vitro and in vivo experiments $(14,16,17,61)$, which points toward species-specific effects. Taken together, the absence of any effect on the expression of ECS enzymes by DEHP in the present study does not mean that DEHP has no impact on endocannabinoid metabolism. Further functional studies, for example, on enzyme activity will be needed to adequately address this aspect.

Summing up, in the human SGBS cell model an upregulation of the ECS receptors CNR1 and TRPV1 as well as the endocannabinoid-metabolizing enzymes FAAH and $M A G L$ - presumably for reducing the endocannabinoid level in the differentiation process - was found during normal adipogenesis. As expected, the secretion of adiponectin and leptin was simultaneously increased. These data implicate the ECS to play a role in normal adipogenesis. As DEHP altered the level of adipokines

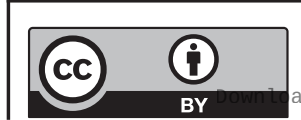

This work is licensed under a Creative Commons Attribution 4.0 International License. ded from Bioscientifica.com at 04/26/2023 11:18:14AM 
secreted by mature adipocytes without affecting the intrinsic ECS, we conclude this DEHP-mediated endocrine impairment to be independent of the intrinsic ECS as endocrine modulator.

\section{Declaration of interest}

The authors declare that there is no conflict of interest that could be perceived as prejudicing the impartiality of the research reported.

\section{Funding}

Jana Ernst, Kristina Schädlich and Urszula Grabiec were supported by the Roux Programme of the Faculty of Medicine, Martin Luther University Halle-Wittenberg (JE FKZ 29/11, KS FKZ 26/06, UG FKZ 29/18). We acknowledge the financial support within the funding programme Open Access Publishing by the German Research Foundation (DFG).

\section{Author contribution statement}

JE performed acquisition, analysis and interpretation of data, conception and design of the study, drafted the article and approved the final manuscript. UG performed acquisition, analysis and interpretation of data and approved the final manuscript. KF performed acquisition, analysis and interpretation of data and approved the final manuscript. FD was a project leader and performed revision and approved the final manuscript. KS was a project leader and performed conception and design of the study and revision and approved the final manuscript.

\section{Acknowledgement}

The authors thank Christine Froehlich and Chalid Ghadban for their excellent technical assistance.

\section{References}

1 Baillie-Hamilton PF. Chemical toxins: a hypothesis to explain the global obesity epidemic. Journal of Alternative and Complementary Medicine 20028 185-192. (https://doi. org/10.1089/107555302317371479)

2 Grün F. Obesogens. Current Opinion in Endocrinology, Diabetes, and Obesity 201017 453-459. (https://doi.org/10.1097/ MED.0b013e32833ddea0)

3 Grün F \& Blumberg B. Endocrine disrupters as obesogens. Molecular and Cellular Endocrinology 2009304 19-29. (https://doi. org/10.1016/j.mce.2009.02.018)

4 Holtcamp W. Obesogens: an environmental link to obesity. Environmental Health Perspectives 2012120 a62-a68. (https://doi. org/10.1289/ehp.120-a62)

5 Schug TT, Janesick A, Blumberg B \& Heindel JJ. Endocrine disrupting chemicals and disease susceptibility. Journal of Steroid Biochemistry and Molecular Biology 2011127 204-215. (https://doi.org/10.1016/j. jsbmb.2011.08.007)

6 Benjamin S, Masai E, Kamimura N, Takahashi K, Anderson RC $\&$ Faisal PA. Phthalates impact human health: epidemiological evidences and plausible mechanism of action. Journal of Hazardous Materials 2017340 360-383. (https://doi.org/10.1016/j. jhazmat.2017.06.036)

7 Heudorf U, Mersch-Sundermann V \& Angerer J. Phthalates: toxicology and exposure. International Journal of Hygiene and Environmental Health 2007210 623-634. (https://doi.org/10.1016/j. ijheh.2007.07.011)
8 Kavlock R, Barr D, Boekelheide K, Breslin W, Breysse P, Chapin R, Gaido K, Hodgson E, Marcus M, Shea K, et al. NTP-CERHR expert panel update on the reproductive and developmental toxicity of di(2-ethylhexyl) phthalate. Reproductive Toxicology 200622 291-399. (https://doi.org/10.1016/j.reprotox.2006.04.007)

9 Buser MC, Murray HE \& Scinicariello F. Age and sex differences in childhood and adulthood obesity association with phthalates: analyses of NHANES 2007-2010. International Journal of Hygiene and Environmental Health 2014217 687-694. (https://doi.org/10.1016/j. ijheh.2014.02.005)

10 James-Todd TM, Huang T, Seely EW \& Saxena AR. The association between phthalates and metabolic syndrome: the National Health and Nutrition Examination Survey 2001-2010. Environmental Health: A Global Access Science Source 201615 52. (https://doi.org/10.1186/ s12940-016-0136-x)

11 Kim JH, Park HY, Bae S, Lim YH \& Hong YC. Diethylhexyl phthalates is associated with insulin resistance via oxidative stress in the elderly: a panel study. PLOS ONE 20138 e71392. (https://doi.org/10.1371/ journal.pone.0071392)

12 Kim JH, Park H, Lee J, Cho G, Choi S, Choi G, Kim SY, Eun SH, Suh E, Kim SK, et al. Association of diethylhexyl phthalate with obesity-related markers and body mass change from birth to 3 months of age. Journal of Epidemiology and Community Health $2016 \mathbf{7 0}$ 466-472. (https://doi.org/10.1136/jech-2015-206315)

13 Smerieri A, Testa C, Lazzeroni P, Nuti F, Grossi E, Cesari S, Montanini L, Latini G, Bernasconi S, Papini AM, et al. Di-(2ethylhexyl) phthalate metabolites in urine show age-related changes and associations with adiposity and parameters of insulin sensitivity in childhood. PLoS ONE 201510 e0117831. (https://doi.org/10.1371/ journal.pone.0117831)

14 Klöting N, Hesselbarth N, Gericke M, Kunath A, Biemann R, Chakaroun R, Kosacka J, Kovacs P, Kern M, Stumvoll M, et al. Di-(2ethylhexyl)-phthalate (DEHP) causes impaired adipocyte function and alters serum metabolites. PLOS ONE 201510 e0143190. (https:// doi.org/10.1371/journal.pone.0143190)

15 Lv Z, Cheng J, Huang S, Zhang Y, Wu S, Qiu Y, Geng Y, Zhang Q Huang G, Ma Q, et al. DEHP induces obesity and hypothyroidism through both central and peripheral pathways in $\mathrm{C} 3 \mathrm{H} / \mathrm{He}$ mice. Obesity 201624 368-378. (https://doi.org/10.1002/oby.21359)

16 Schmidt JS, Schaedlich K, Fiandanese N, Pocar P \& Fischer B. Effects of di(2-ethylhexyl) phthalate (DEHP) on female fertility and adipogenesis in C3H/N mice. Environmental Health Perspectives 2012 120 1123-1129. (https://doi.org/10.1289/ehp.1104016)

17 Biemann R, Navarrete Santos A, Navarrete Santos A, Riemann D, Knelangen J, Blüher M, Koch H \& Fischer B. Endocrine disrupting chemicals affect the adipogenic differentiation of mesenchymal stem cells in distinct ontogenetic windows. Biochemical and Biophysical Research Communications 2012417 747-752. (https://doi. org/10.1016/j.bbrc.2011.12.028)

18 Di Marzo V. 'Endocannabinoids' and other fatty acid derivatives with cannabimimetic properties: biochemistry and possible physiopathological relevance. Biochimica and Biophysica Acta 1998 1392 153-175. (https://doi.org/10.1016/s0005-2760(98)00042-3)

19 Matsuda LA, Lolait SJ, Brownstein MJ, Young AC \& Bonner TI. Structure of a cannabinoid receptor and functional expression of the cloned cDNA. Nature 1990346 561-564. (https://doi. $\operatorname{org} / 10.1038 / 346561 \mathrm{a} 0)$

20 Munro S, Thomas KL \& Abu-Shaar M. Molecular characterization of a peripheral receptor for cannabinoids. Nature 1993365 61-65. (https://doi.org/10.1038/365061a0)

21 Pertwee RG \& Ross RA. Cannabinoid receptors and their ligands. Prostaglandins, Leukotrienes, and Essential Fatty Acids 200266 101-121. (https://doi.org/10.1054/plef.2001.0341)

22 Ross RA. The enigmatic pharmacology of GPR55. Trends in Pharmacological Sciences 200930 156-163. (https://doi.org/10.1016/j. tips.2008.12.004)

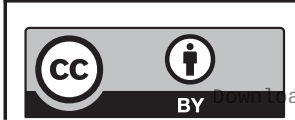

This work is licensed under a Creative Commons Attribution 4.0 International License. ded from Bioscientifica, com at 04/26/2023 11:18:14AM 
23 Di Marzo V \& de Petrocellis L. Endocannabinoids as regulators of transient receptor potential (TRP) channels: a further opportunity to develop new endocannabinoid-based therapeutic drugs. Current Medicinal Chemistry 201017 1430-1449. (https://doi. org/10.2174/092986710790980078)

24 Pistis M \& Melis M. From surface to nuclear receptors: the endocannabinoid family extends its assets. Current Medicinal Chemistry 201017 1450-1467. (https://doi. org/10.2174/092986710790980014)

25 Okamoto Y, Tsuboi K \& Ueda N. Enzymatic formation of anandamide. Vitamins and Hormones 200981 1-24. (https://doi. org/10.1016/S0083-6729(09)81001-7)

26 Ueda N, Tsuboi K, Uyama T \& Ohnishi T. Biosynthesis and degradation of the endocannabinoid 2-arachidonoylglycerol. BioFactors 201137 1-7. (https://doi.org/10.1002/biof.131)

27 Dinh TP, Carpenter D, Leslie FM, Freund TF, Katona I, Sensi SL, Kathuria S \& Piomelli D. Brain monoglyceride lipase participating in endocannabinoid inactivation. PNAS 200299 10819-10824. (https:// doi.org/10.1073/pnas.152334899)

28 Fezza F, de Simone C, Amadio D \& Maccarrone M. Fatty acid amide hydrolase: a gate-keeper of the endocannabinoid system. Sub-Cellular Biochemistry 200849 101-132. (https://doi.org/10.1007/978-1-40208831-5_4)

29 Forner-Piquer I, Maradonna F, Gioacchini G, Santangeli S, Allarà M, Piscitelli F, Habibi HR, Di Marzo V \& Carnevali O. Dose-specific effects of di-isononyl phthalate on the endocannabinoid system and on liver of female zebrafish. Endocrinology $2017 \mathbf{1 5 8} 3462-3476$ (https://doi.org/10.1210/en.2017-00458)

30 Forner-Piquer I, Mylonas CC, Calduch-Giner J, Maradonna F, Gioacchini G, Allarà M, Piscitelli F, Di Marzo V, Pérez-Sánchez J \& Carnevali O. Endocrine disruptors in the diet of male Sparus aurata: modulation of the endocannabinoid system at the hepatic and central level by di-isononyl phthalate and bisphenol A. Environment International 2018119 54-65. (https://doi.org/10.1016/j. envint.2018.06.011)

31 Forner-Piquer I, Santangeli S, Maradonna F, Rabbito A, Piscitelli F, Habibi HR, Di Marzo V \& Carnevali O. Disruption of the gonadal endocannabinoid system in zebrafish exposed to diisononyl phthalate. Environmental Pollution 2018241 1-8. (https://doi. org/10.1016/j.envpol.2018.05.007)

32 Pomatto V, Cottone E, Cocci P, Mozzicafreddo M, Mosconi G, Nelson ER, Palermo FA \& Bovolin P. Plasticizers used in food-contact materials affect adipogenesis in 3T3-L1 cells. Journal of Steroid Biochemistry and Molecular Biology 2018178 322-332. (https://doi. org/10.1016/j.jsbmb.2018.01.014)

33 Bennetzen MF, Nielsen TS, Paulsen SK, Bendix J, Fisker S, Jessen N, Lund S, Richelsen B \& Pedersen SB. Reduced cannabinoid receptor 1 protein in subcutaneous adipose tissue of obese. European Journal of Clinical Investigation 201040 121-126. (https://doi.org/10.1111/ j.1365-2362.2009.02231.x)

34 Blüher M, Engeli S, Klöting N, Berndt J, Fasshauer M, Bátkai S, Pacher P, Schön MR, Jordan J \& Stumvoll M. Dysregulation of the peripheral and adipose tissue endocannabinoid system in human abdominal obesity. Diabetes 200655 3053-3060. (https://doi. org/10.2337/db06-0812)

35 Engeli S, Böhnke J, Feldpausch M, Gorzelniak K, Janke J, Bátkai S, Pacher P, Harvey-White J, Luft FC, Sharma AM, et al. Activation of the peripheral endocannabinoid system in human obesity. Diabetes 200554 2838-2843. (https://doi.org/10.2337/diabetes.54.10.2838)

36 Engeli S, Lehmann AC, Kaminski J, Haas V, Janke J, Zoerner AA, Luft FC, Tsikas D \& Jordan J. Influence of dietary fat intake on the endocannabinoid system in lean and obese subjects. Obesity 201422 E70-E76. (https://doi.org/10.1002/oby.20728)

37 Kempf K, Hector J, Strate T, Schwarzloh B, Rose B, Herder C, Martin S \& Algenstaedt P. Immune-mediated activation of the endocannabinoid system in visceral adipose tissue in obesity.
Hormone and Metabolic Research 200739 596-600. (https://doi org/10.1055/s-2007-984459)

38 Bellocchio L, Cervino C, Vicennati V, Pasquali R \& Pagotto U. Cannabinoid type 1 receptor: another arrow in the adipocytes bow. Journal of Neuroendocrinology 200820 (Supplement 1) 130-138. (https://doi.org/10.1111/j.1365-2826.2008.01682.x)

39 Gary-Bobo M, Elachouri G, Scatton B, Le Fur G, Oury-Donat F \& Bensaid M. The cannabinoid CB1 receptor antagonist Rimonabant (SR141716) inhibits cell proliferation and increases markers of adipocyte maturation in cultured mouse 3T3 F442A preadipocytes. Molecular Pharmacology 200669 471-478. (https://doi.org/10.1124/ mol.105.015040)

40 Gasperi V, Fezza F, Pasquariello N, Bari M, Oddi S, Agrò AF \& Maccarrone M. Endocannabinoids in adipocytes during differentiation and their role in glucose uptake. Cellular and Molecular Life Sciences 200764 219-229. (https://doi.org/10.1007/s00018-0066445-4)

41 Pagano C, Pilon C, Calcagno A, Urbanet R, Rossato M, Milan G, Bianchi K, Rizzuto R, Bernante P, Federspil G, et al. The endogenous cannabinoid system stimulates glucose uptake in human fat cells via phosphatidylinositol 3-kinase and calcium-dependent mechanisms. Journal of Clinical Endocrinology and Metabolism 200792 4810-4819. (https://doi.org/10.1210/jc.2007-0768)

42 Tam J, Cinar R, Liu J, Godlewski G, Wesley D, Jourdan T, Szanda G, Mukhopadhyay B, Chedester L, Liow JS, et al. Peripheral cannabinoid-1 receptor inverse agonism reduces obesity by reversing leptin resistance. Cell Metabolism 201216 167-179. (https://doi. org/10.1016/j.cmet.2012.07.002)

43 Löfgren P, Sjölin E, Wåhlen K \& Hoffstedt J. Human adipose tissue cannabinoid receptor 1 gene expression is not related to fat cell function or adiponectin level. Journal of Clinical Endocrinology and Metabolism 200792 1555-1559. (https://doi.org/10.1210/jc.20062240)

44 Thornton-Jones ZD, Kennett GA, Benwell KR, Revell DF, Misra A, Sellwood DM, Vickers SP \& Clifton PG. The cannabinoid CB1 receptor inverse agonist, Rimonabant, modifies body weight and adiponectin function in diet-induced obese rats as a consequence of reduced food intake. Pharmacology, Biochemistry, and Behavior $2006 \mathbf{8 4}$ 353-359. (https://doi.org/10.1016/j.pbb.2006.06.001)

45 Matias I, Gonthier MP, Orlando P, Martiadis V, de Petrocellis L, Cervino C, Petrosino S, Hoareau L, Festy F, Pasquali R, et al. Regulation, function, and dysregulation of endocannabinoids in models of adipose and beta-pancreatic cells and in obesity and hyperglycemia. Journal of Clinical Endocrinology and Metabolism 2006 91 3171-3180. (https://doi.org/10.1210/jc.2005-2679)

46 Teixeira D, Pestana D, Faria A, Calhau C, Azevedo I \& Monteiro R. Modulation of adipocyte biology by $\delta(9)$-tetrahydrocannabinol. Obesity 201018 2077-2085. (https://doi.org/10.1038/oby.2010.100)

47 Ahn S, Yi S, Seo WJ, Lee MJ, Song YK, Baek SY, Yu J, Hong SH, Lee J, Shin DW, et al. A cannabinoid receptor agonist $\mathrm{N}$-arachidonoyl dopamine inhibits adipocyte differentiation in human mesenchymal stem cells. Biomolecules and Therapeutics 201523 218-224. (https:// doi.org/10.4062/biomolther.2014.137)

48 Bisset KM, Dhopeshwarkar AS, Liao C \& Nicholson RA. The G protein-coupled cannabinoid-1 (CB1) receptor of mammalian brain: inhibition by phthalate esters in vitro. Neurochemistry International 201159 706-713. (https://doi.org/10.1016/j.neuint.2011.06.019)

49 Sarath Josh MK, Pradeep S, Vijayalekshmi Amma KS, Balachandran S, Abdul Jaleel UC, Doble M, Spener F \& Benjamin S. Phthalates efficiently bind to human peroxisome proliferator activated receptor and retinoid $\mathrm{X}$ receptor $\alpha, \beta, \gamma$ subtypes: an in silico approach. Journal of Applied Toxicology 201434 754-765. (https://doi.org/10.1002/ jat.2902)

50 Fischer-Posovszky P, Newell FS, Wabitsch M \& Tornqvist HE. Human SGBS cells - a unique tool for studies of human fat cell biology. Obesity Facts 20081 184-189. (https://doi.org/10.1159/000145784)

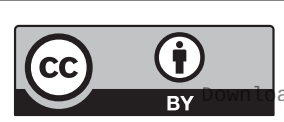

This work is licensed under a Creative Commons Attribution 4.0 International License. 
51 Wabitsch M, Brenner RE, Melzner I, Braun M, Möller P, Heinze E, Debatin KM \& Hauner H. Characterization of a human preadipocyte cell strain with high capacity for adipose differentiation. International Journal of Obesity and Related Metabolic Disorders 200125 8-15. (https://doi.org/10.1038/sj.ijo.0801520)

52 Biemann R, Fischer B \& Navarrete Santos A. Adipogenic effects of a combination of the endocrine-disrupting compounds bisphenol A, diethylhexylphthalate, and tributyltin. Obesity Facts 20147 48-56. (https://doi.org/10.1159/000358913)

53 Schaedlich K, Gebauer S, Hunger L, Beier LS, Koch HM, Wabitsch M, Fischer B \& Ernst J. DEHP deregulates adipokine levels and impairs fatty acid storage in human SGBS-adipocytes. Scientific Reports $2018 \mathbf{8}$ 3447. (https://doi.org/10.1038/s41598-018-21800-4)

54 OECD. Health at a Glance 2011: OECD Indicators. Paris, France: OECD Publishing, 2011. (https://doi.org/10.1787/health_glance2011-en)

55 Kavlock R, Boekelheide K, Chapin R, Cunningham M, Faustman E, Foster P, Golub M, Henderson R, Hinberg I, Little R, et al. NTP Center for the Evaluation of Risks to Human Reproduction: phthalates expert panel report on the reproductive and developmental toxicity of di(2-ethylhexyl) phthalate. Reproductive Toxicology 200216 529-653. (https://doi.org/10.1016/S0890-6238(02)00032-1)

56 Gillum N, Karabekian Z, Swift LM, Brown RP, Kay MW \& Sarvazyan N. Clinically relevant concentrations of di (2-ethylhexyl) phthalate (DEHP) uncouple cardiac syncytium. Toxicology and
Applied Pharmacology 2009236 25-38. (https://doi.org/10.1016/j. taap.2008.12.027)

57 Spoto B, Fezza F, Parlongo G, Battista N, Sgro' E, Gasperi V, Zoccali C $\&$ Maccarrone M. Human adipose tissue binds and metabolizes the endocannabinoids anandamide and 2-arachidonoylglycerol. Biochimie 200688 1889-1897. (https://doi.org/10.1016/j.biochi.2006.07.019)

58 Roche R, Hoareau L, Bes-Houtmann S, Gonthier MP, Laborde C, Baron JF, Haffaf Y, Cesari M \& Festy F. Presence of the cannabinoid receptors, $\mathrm{CB} 1$ and $\mathrm{CB} 2$, in human omental and subcutaneous adipocytes. Histochemistry and Cell Biology 2006126 177-187. (https://doi.org/10.1007/s00418-005-0127-4)

59 Hauner H, Röhrig K, Spelleken M, Liu LS \& Eckel J. Development of insulin-responsive glucose uptake and GLUT4 expression in differentiating human adipocyte precursor cells. International Journal of Obesity and Related Metabolic Disorders 199822 448-453. (https:// doi.org/10.1038/sj.ijo.0800606)

60 Pederson $\mathrm{T} \&$ Rondinone CM. Regulation of proteins involved in insulin signaling pathways in differentiating human adipocytes. Biochemical and Biophysical Research Communications 2000276 162-168. (https://doi.org/10.1006/bbrc.2000.3429)

61 Jia Y, Liu T, Zhou L, Zhu J, Wu J, Sun D, Xu J, Wang Q, Chen H, Xu F, et al. Effects of di-(2-ethylhexyl) phthalate on lipid metabolism by the JAK/STAT pathway in rats. International Journal of Environmental Research and Public Health 2016 13. (https://doi.org/10.3390/ ijerph13111085)

Received in final form 17 December 2019

Accepted 6 January 2020

Accepted Manuscript published online 7 January 2020 https://ec.bioscientifica.com

https://doi.org/10.1530/EC-19-0548 (c) 2020 The authors Published by Bioscientifica Ltd

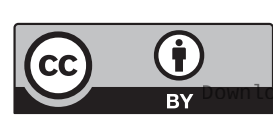

This work is licensed under a Creative Commons Attribution 4.0 International License.

ded from Bioscientifica.com at 04/26/2023 11:18:14AM 